\title{
TINGKAT PENYERAPAN NITROGEN DAN FOSFOR PADA BUDIDAYA RUMPUT LAUT BERBASIS IMTA (INTEGRATED MULTI-TROPHIC AQUACULTURE) DI TELUK GERUPUK, LOMBOK TENGAH, NUSA TENGGARA BARAT
}

\author{
Erna Yuniarsih","*), Kukuh Nirmala"*), dan I Nyoman Radiarta"**) \\ *) Sekretariat Direktorat Jenderal Perikanan Budidaya \\ Gedung Menara 165 Lt. 23, Jl. T.B. Simatupang Kav. 1, Cilandak Timur, Jakarta \\ E-mail: ceu2_rna@yahoo.com \\ **) Departemen Budidaya Perikanan, Fakultas Perikanan dan IImu Kelautan, IPB \\ Jl. Agatis, Kampus IPB Dramaga, Bogor 16680 \\ ***) Pusat Penelitian dan Pengembangan Perikanan Budidaya \\ Jl. Ragunan 20, Pasar Minggu, Jakarta Selatan 12540 \\ (Naskah diterima: 6 Juni 2014; Revisi final: 16 Oktober 2014; \\ Disetujui publikasi: 10 November 2014)
}

\begin{abstract}
ABSTRAK
Pengembangan budidaya laut berbasis IMTA (Integrated Multi-Trophic Aquaculture) merupakan suatu metode yang dirancang untuk mengatasi masalah lingkungan yang terkait dengan penggunaan pakan pada kegiatan akuakultur. Penelitian ini bertujuan untuk menganalisis tingkat penyerapan nitrogen dan fosfor pada budidaya rumput laut berbasis IMTA di Teluk Gerupuk Kabupaten Lombok Tengah. Rumput laut jenis Kappaphycus alvarezii dan Eucheuma spinosum dibudidayakan dengan metode rawai (long line). Pengamatan terhadap rumput laut dan kondisi perairan dilakukan setiap 15 hari; mulai hari ke-0 sampai hari ke-45. Hasil penelitian menunjukkan bahwa adanya perbedaan tingkat penyerapan nitrogen dan fosfor antara dua jenis rumput laut yang dibudidayakan. Total penyerapan nitrogen rumput laut $K$. alvarezii di lokasi IMTA mencapai 86,95 ton $\mathrm{N} /$ ha/tahun atau lebih tinggi $24,6 \%$ dibandingkan dengan $E$. spinosum yang mencapai 69,78 ton $\mathrm{N} / \mathrm{ha}$ /tahun. Sedangkan untuk tingkat penyerapan fosfor, K. alvarezii mencapai 20,56 ton P/ha/tahun atau lebih tinggi 136,7\% dibandingkan dengan E. spinosum yang hanya mencapai 8,69 ton $\mathrm{P} / \mathrm{ha} / \mathrm{tahun}$. Berdasarkan luasan kawasan potensial budidaya rumput laut di Teluk Gerupuk, maka potensi penyerapan nitrogen dan fosfor untuk rumput laut $K$. alvarezii di kawasan ini masing-masing mencapai 27.996,93 ton N/tahun dan 6.619,16 ton P/tahun. Sedangkan untuk $E$. spinosum potensi penyerapan nitrogen dan fosfor masing-masing mencapai $22.470,02$ ton $\mathrm{N} /$ tahun dan $2.796,82$ ton $\mathrm{P} /$ tahun. Penerapan budidaya rumput laut berbasis IMTA secara jelas memberikan keuntungan ekonomi dan ekologi dengan adanya peningkatan biomassa dan perbaikan kondisi lingkungan budidaya.
\end{abstract}

KATA KUNCl: IMTA, penyerapan nitrogen dan fosfor, Kappaphycus alvarezii, Eucheuma spinosum, Teluk Gerupuk

ABSTRACT: Nitrogen and phosphorus absorption levels on the seaweed aquaculture based on IMTA (Integrated multi-trophic aquaculture) system in Gerupuk Bay, Central Lombok, West Nusa Tenggara. By: Erna Yuniarsih, Kukuh Nirmala, and I Nyoman Radiarta 


\begin{abstract}
Mariculture development based on IMTA (Integrated Multi-Trophic Aquaculture) is a method that design to address the issues on environmental problems related to the use of feed in aquaculture. The aims of this research was to analyze the level of nitrogen and phosphorus absorption from seaweed aquaculture based on IMTA system in Gerupuk Bay, Central Lombok. Two difference species of seaweeds, Kappaphycus alvarezii and Eucheuma spinosum, were cultured using long line system. Seaweed and sea water parameter were investigated and analyzed every 15 days starting from day 0 to 45. The result showed that there were different level of nitrogen and phosphorus uptake between two species of seaweeds. The total nitrogen absorption of K. alvarezii in IMTA area was about 86.95 ton N/ha/year or $24.6 \%$ higher than $E$. spinosum in the same area that was reached 69.78 ton N/ha/year. Meanwhile the level of phosphorus absorption of $\boldsymbol{K}$. alvarezii in IMTA area was accounted for 20.56 ton $P /$ ha/year or $136.7 \%$ higher than $E$. spinosum that was only reached 8.69 ton $P /$ ha/year. Based on potential area of seaweed aquaculture in Gerupuk Bay, the potential of nitrogen and phosphorus absorption for $K$. alvarezii in this area was reached 27,996.93 ton N/year and 6,619.16 ton P/year, respectively. While for E. spinosum, the potential of nitrogen and phosphorus absorption was reached 22,470.02 ton N/ year and 2,796.82 ton P/year, respectively. Seaweeds culture using IMTA system obviously give an economical and ecological advantaged by increasing the biomass and improving water quality condition.
\end{abstract}

KEYWORDS: IMTA, nitrogen and phosphorus absorption, Kappaphycus alvarezii, Eucheuma spinosum, Gerupuk Bay

\section{PENDAHULUAN}

Budidaya laut dengan konsep budidaya multi-trofik terintegrasi (Integrated MultiTrophic Aquaculture/IMTA) merupakan salah satu metode budidaya yang dapat diterapkan untuk mengatasi masalah lingkungan, seperti akumulasi limbah dari penggunaan pakan pada kegiatan akuakultur (Soto, 2009). Prinsip dasar dari penerapan IMTA adalah mendaur ulang limbah budidaya yang dihasilkan oleh spesies utama menjadi sumber energi dan nutrien bagi komoditas budidaya lainnya, sehingga menghasilkan produk yang dapat dipanen, dan sekaligus dapat mengurangi dampak lingkungan (Ren et al., 2012). Konsep IMTA adalah menggabungkan kegiatan pemeliharaan beberapa spesies dari tingkat trofik yang berbeda yaitu antara organisme akuakultur yang diberi pakan (ikan) dengan organisme akuakultur penyerap bahan inorganik (rumput laut), dan organisme akuakultur penyerap bahan organik (suspension dan deposit feeder, contoh kekerangan) (Troell et al., 2009). Efektivitas sistem ini telah teruji di beberapa negara di antaranya Kanada, Cina, Norwegia, dan Amerika (Soto, 2009).

Rumput laut merupakan salah satu komoditas ekonomi penting yang menjadi unggulan Indonesia. Menurut statistik FAO tahun 2010 , produksi rumput laut Indonesia menempati peringkat kedua setelah Cina, dengan total produksi sebesar 3,90 juta ton atau $20,60 \%$ dari total produksi rumput laut dunia (FAO, 2012). Spesies rumput laut yang banyak dibudidayakan di perairan Indonesia adalah jenis Kappaphycus alvarezii dan Eucheuma spinosum (Atmadja et al., 2012). Hal ini disebabkan oleh teknik budidaya yang mudah dan permintaan pasar yang cukup tinggi. Sentra pengembangan budidaya rumput laut di Indonesia tersebar di beberapa provinsi di antaranya: Sulawesi Tengah, Sulawesi Selatan, Nusa Tenggara Timur, Bali, Jawa Timur, Sulawesi Tenggara, dan Nusa Tenggara Barat. Metode budidaya rumput laut yang telah berkembang saat ini dan dikenal secara umum oleh masyarakat meliputi metode lepas dasar, metode rakit apung, dan metode rawai (Parenrengi et al., 2011 1). Budidaya rumput laut yang berkembang pada umumnya masih bersifat monokultur. Berdasarkan perkembangan budidaya laut sekarang ini, penerapan IMTA dalam sistem budidaya laut di Indonesia perlu dikembangkan. Kegiatan budidaya rumput laut berbasis IMTA dapat dijadikan salah satu aktivitas yang mendukung penerapan kebijakan ekonomi biru yang tengah menjadi perhatian utama Kementerian Kelautan dan Perikanan (KKP) saat ini. Pembangunan kelautan dan perikanan berbasis pada kebijakan ekonomi biru didasarkan pada beberapa pendekatan yaitu adanya integrasi yang selaras; pengembangan 
berdasarkan kawasan; sistem produksi bersih (zero waste); bermanfaat bagi seluruh masyarakat; dan berkelanjutan dengan cara menjaga keseimbangan antara pemanfaatan sumber daya alam dan pelestarian lingkungan dan antara produksi dan konsumsi (KKP, 2013).

Dalam kerangka IMTA, rumput laut memiliki peranan sebagai biofilter dan penghasil biomassa yang bernilai ekonomis, di mana limbah budidaya yang terbuang di laut baik berupa hasil metabolisme ataupun sisa pakan yang tidak termakan merupakan sumber nutrien yang sangat bermanfaat untuk pertumbuhan rumput laut (Troell et al., 2003). Beberapa kajian tentang budidaya rumput laut berbasis IMTA telah dilakukan namun umumnya kajian tersebut dilakukan di kawasan subtropis (Soto, 2009). Hasil penelitian Troell et al. (1997) di Teluk Metri, Chilli menunjukkan bahwa Gracilaria yang dibudidayakan pada jarak 10 m dari karamba jaring apung (KJA) ikan salmon mengalami peningkatan biomassa $40 \%$ lebih tinggi dibandingkan dengan pertumbuhan Gracilaria pada jarak 150 m dan $1 \mathrm{~km}$ dari KJA. Hasil penelitian Huo et al. (2012) juga menunjukkan adanya keuntungan dengan mengombinasikan budidaya alga merah G. verrucosa dengan ikan di perairan Timur Laut Cina, di mana biomassa G. verrucosa mengalami peningkatan 42 kali lipat dibandingkan dengan biomassa awal. Berdasarkan Nobre et al. (2010), penerapan IMTA pada budidaya abalon dengan rumput laut telah menurunkan kadar nitrogen $(\mathrm{N})$ dan fosfor $(P)$ perairan sebesar $44 \%$ dan $23 \%$ dibandingkan dengan budidaya abalon monokultur. Sedangkan menurut Abreu et al. (2009), 100 ha Gracilaria dapat menyerap $80 \%$ limbah nitrogen yang dihasilkan oleh 1.500 ton ikan salmon.

Dalam rangka mengkaji penerapan budidaya laut berbasis IMTA di Indonesia, maka perlu dilakukan kajian tentang peran rumput laut sebagai komponen IMTA dalam mendukung peningkatan biomassa dan perbaikan kondisi lingkungan perairan agar aktivitas tersebut dapat berkelanjutan. Tujuan dari penelitian ini adalah untuk mengkaji tingkat penyerapan nitrogen dan fosfor pada budidaya rumput laut, Kappaphycus alvarezii dan Eucheuma spinosum, berbasis IMTA di Teluk Gerupuk Kabupaten Lombok Tengah, NTB. Selain tingkat penyerapan nitrogen dan fosfor, kondisi kualitas perairan secara umum di sis- tem IMTA juga dianalisis. Hasil dari penelitian ini diharapkan dapat menjadi data dasar pengembangan budidaya laut berbasis IMTA di Indonesia, sehingga dapat meningkatkan produktivitas budidaya laut dengan tetap menjaga kondisi lingkungan akuakultur, sehingga aktivitasnya dapat berkelanjutan.

\section{BAHAN DAN METODE}

Penelitian ini dilaksanakan pada bulan September-Oktober 2013 di Perairan Teluk Gerupuk Kabupaten Lombok Tengah Provinsi Nusa Tenggara Barat. Secara geografis Teluk Gerupuk terletak antara 116⒈'40"$116^{\circ} 21^{\prime} 00^{\prime \prime}$ Lintang Selatan dan 9०53'45"9॰55’45" Bujur Timur (Gambar 1A). Berbagai aktivitas pemanfaatan kawasan telah berkembang di Teluk Gerupuk, meliputi: budidaya laut, penangkapan benih lobster, dan pariwisata (surfing). Pemanfaatan kawasan tersebut terbagi dengan baik sesuai dengan karakteristik perairan dan kedalaman perairan (Radiarta \& Rasidi, 2012).

Metode budidaya rumput laut yang digunakan pada penelitian ini berdasarkan SNI 7579.2:2010 tentang produksi budidaya rumput laut kotoni (Eucheuma cottonii). Bibit rumput laut yang digunakan adalah jenis Kappaphycus alvarezii strain Maumere dan Eucheuma spinosum yang berasal dari $\mathrm{Na}$ tional Seaweed Center, Balai Budidaya Laut Lombok. Budidaya rumput laut menggunakan metode rawai (long line) dengan ukuran $50 \mathrm{mx}$ $50 \mathrm{~m}$. Terdapat tiga unit long line rumput laut yang disiapkan dalam penelitian ini. Dua unit long line diletakkan pada sistem IMTA yaitu masing-masing di sisi barat $\left(\mathrm{K}_{\mathrm{a}} \mathrm{B}=K\right.$. alvarezii barat; $\mathrm{E}_{\mathrm{s}} \mathrm{B}=$ E. spinosum barat) dan sisi timur $\left(\mathrm{K}_{\mathrm{a}} \mathrm{T}=K\right.$. alvarezii timur; $\mathrm{E}_{\mathrm{s}} \mathrm{T}=\mathrm{E}$. spinosum $\mathrm{ti}-$ mur) unit karamba jaring apung (KJA), dengan jarak masing-masing 20 m (Gambar 1B). KJA merupakan titik tengah dari sistem IMTA yang diaplikasikan. KJA yang digunakan adalah jaring ganda yang terdiri atas empat lubang dengan ukuran masing-masing lubang adalah $3 \mathrm{~m} \times 3 \mathrm{~m} \times 3 \mathrm{~m}$. Jaring bagian atas dipergunakan untuk memelihara ikan kerapu cantang (500 ekor ikan/lubang) dan jaring bagian bawah dipergunakan untuk ikan baronang (200 ekor/lubang). Selanjutnya satu unit long line rumput laut digunakan sebagai kontrol $\left(\mathrm{K}_{\mathrm{a}} \mathrm{K}=\right.$ $K$. alvarezii kontrol; $\mathrm{E}_{\mathrm{s}} \mathrm{K}=E$. spinosum kontrol) diletakkan pada lokasi dekat mulut teluk dengan jarak sekitar $550 \mathrm{~m}$ dari sistem IMTA (Gambar 1B). 
Parameter yang diamati pada penelitian ini meliputi performa pertumbuhan rumput laut dan kondisi kualitas perairan. Waktu sampling kualitas air dilakukan bersamaan dengan sampling rumput laut yaitu setiap 15 hari dimulai dari hari ke-0, 15, 30, dan 45. Alat dan metode yang digunakan dalam pengukuran parameter kualitas air dan rumput laut seperti tercantum pada Tabel 1. Pengukuran dan pengambilan sampel air laut dilakukan secara vertikal di enam stasiun pada kedalaman $0 \mathrm{~m}$, $3 \mathrm{~m}$, dan dekat dasar perairan (Gambar 1B).
Metode pengambilan dan preservasi sampel air mengacu pada APHA (2005).

Data kualitas air yang dikumpulkan kemudian dianalisis secara deskriptif dan spasial. Analisis spasial ditampilkan secara vertikal. Perangkat lunak yang digunakan dalam analisis ini adalah Ocean Data View (ODV). Untuk melakukan analisis spasial, seluruh data yang terkumpul diinterpolasi dengan teknik VG gridding (Schlitzer, 2011).

Untuk sampel rumput laut, analisis data yang dilakukan meliputi laju pertumbuhan

A
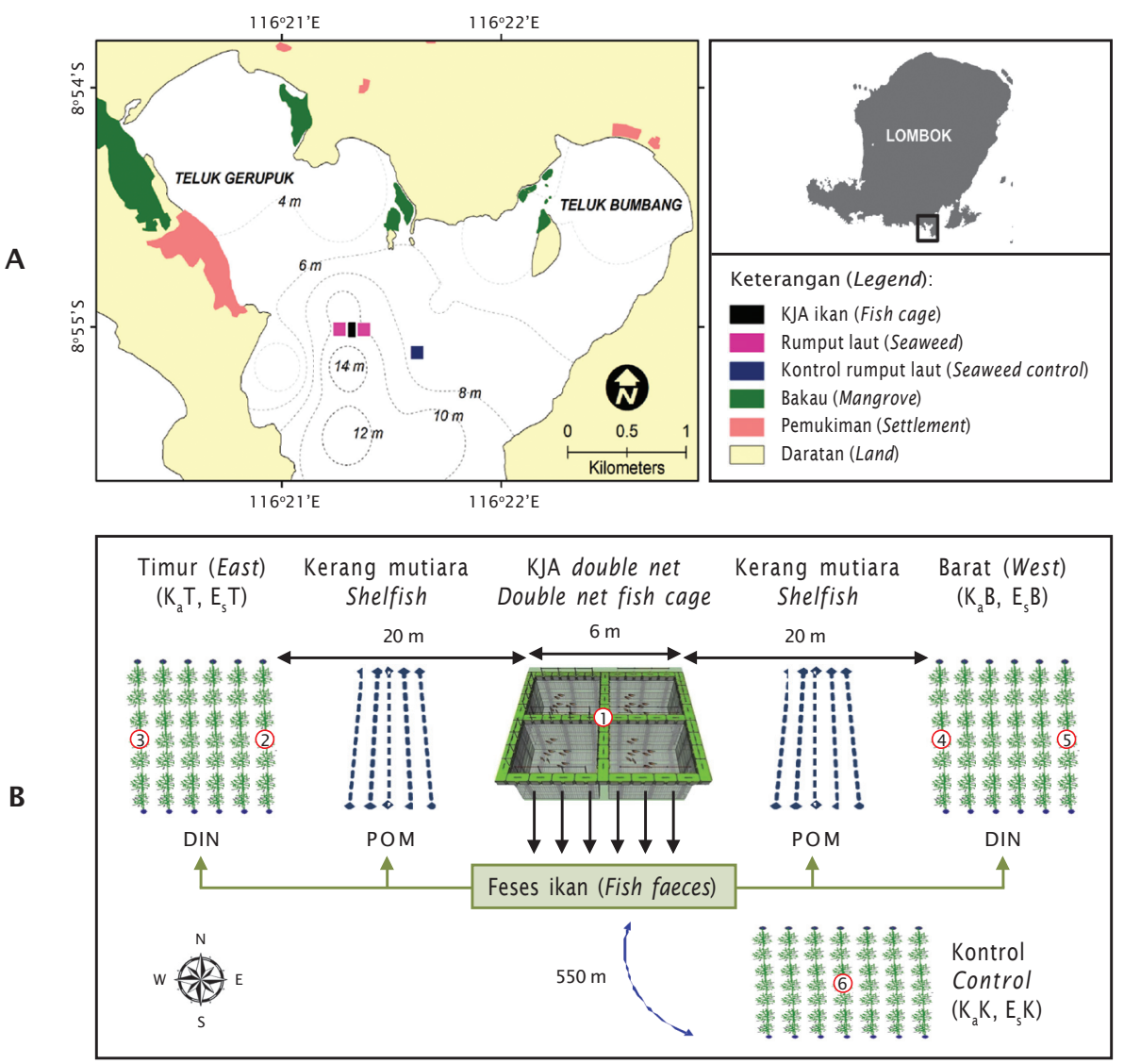

Keterangan (Note):

1 = Titik sampling air KJA (Fish cage water sampling spot), $2 \& 3=$ Titik sampling air Barat (West water sampling spot), 4 \& 5 = Titik sampling air Timur (East water sampling spot), $6=$ Titik sampling kontrol (Control water sampling spot). DIN = Nutrien inorganik terlarut (Dissolved inorganic nutrient). Lingkaran merah menunjukkan lokasi stasiun pengamatan kualitas perairan (The red circle indicate water quality sampling stations)

Gambar 1. Lokasi penelitian di Teluk Gerupuk, Lombok Tengah, Nusa Tenggara Barat (A) dan desain budidaya laut berbasis IMTA (B)

Figure 1. The study area in Gerupuk Bay, Central Lombok, West Nusa Tenggara ( $A$ ) and mariculture based on IMTA system design (B) 
Tabel 1. Pengamatan parameter kualitas air dan rumput laut di Teluk Gerupuk

Table 1. Observation of water quality parameters and seaweeds aquaculture in Gerupuk Bay

\begin{tabular}{|c|c|c|c|}
\hline $\begin{array}{l}\text { Parameter } \\
\text { Parameters }\end{array}$ & $\begin{array}{l}\text { Jenis sampel } \\
\text { Type of sample }\end{array}$ & $\begin{array}{l}\text { Metode } \\
\text { Methods }\end{array}$ & $\begin{array}{l}\text { Lokasi analisis } \\
\text { Analyze location }\end{array}$ \\
\hline Total N (N total) & Rumput laut (Seaweed) & Kjeldahl & Seameo Biotrop \\
\hline Total P (P total $)$ & Rumput laut (Seaweed) & $\begin{array}{l}\mathrm{HNO}_{3}-\mathrm{HClO}_{4}^{-} \\
\text {Spektrofometri }\end{array}$ & Seameo Biotrop \\
\hline Karbohidrat (Carbohydrate) & Rumput laut (Seaweed) & Luff Schoorl & Seameo Biotrop \\
\hline Suhu (Temperature) & Air laut (Sea water) & YSI Pro & In situ \\
\hline Salinitas (Salinity) & Air laut (Sea water) & YSI Pro & In situ \\
\hline $\begin{array}{l}\text { Oksigen te rlarut (DO) } \\
\text { Dissolved oxygen }\end{array}$ & Air laut (Sea water) & DO meter & In situ \\
\hline $\mathrm{pH}$ & Air laut (Sea water) & YSI Pro & In situ \\
\hline TDS (Total dissolved oxygen) & Air laut (Sea water) & YSI Pro & In situ \\
\hline Nitrat $\left(\mathrm{NO}_{3}-\mathrm{N}\right)$ & Air laut (Sea water) & Spektrofotome tri & BBL Lombok \\
\hline Nitrit $\left(\mathrm{NO}_{2}-\mathrm{N}\right)$ & Air laut (Sea water) & Spektrofotome tri & BBL Lombok \\
\hline Amonium $\left(\mathrm{NH}_{3}-\mathrm{N}\right)$ & Air laut (Sea water) & Spektrofotometri & BBL Lombok \\
\hline Fosfor $\left(\mathrm{PO}_{4}^{-}-\mathrm{P}\right)$ & Air laut (Sea water) & Spektrofotome tri & BBL Lombok \\
\hline Kecerahan (Transparency) & Air laut (Sea water) & Sechi disc & In situ \\
\hline $\begin{array}{l}\text { Kec epatan arus } \\
\text { Water current }\end{array}$ & Air laut (Sea water) & Current-meter & In situ \\
\hline
\end{tabular}

harian rumput laut dan penyerapan nitrogen (N) dan fosfor (P) pada rumput laut. Laju pertumbuhan harian (Daily growth rate/DGR) dihitung dengan persamaan sebagai berikut (Luning, 1990):

$$
\operatorname{DGR}(\%)=\frac{\ln (\mathrm{Wt} / \mathrm{Wo})}{\mathrm{T}_{2}-\mathrm{T}_{1}} \times 100 \%
$$

di mana:

$\mathrm{Wt}=$ Bobot pada waktu $\mathrm{T}_{2}(\mathrm{~g})$

Wo = Bobot pada waktu $\mathrm{T}_{1}(\mathrm{~g})$

$\mathrm{T}_{1}$ dan $\mathrm{T}_{2}=$ Waktu pemeliharaan (hari)

Penyerapan $\mathrm{N}$ dan P rumput laut dapat dilihat dengan jumlah kandungan nitrogen dan fosfor pada rumput laut yang diamati setiap 15 hari sekali. Laju penyerapan $\mathrm{N}$ dan P pada rumput laut dihitung dengan persamaan sebagai berikut (Kitadai et al., 2007):

$$
\mathrm{P}_{\mathrm{ob}}=(\mathrm{Ct}-\mathrm{Co}) \times \alpha / \mathrm{t}
$$

di mana :

$\mathrm{P}_{\mathrm{ob}}=$ Laju penyerapan $\mathrm{N}$ dan $\mathrm{P}$ rumput laut per area budidaya $\left(\mathrm{mg} / \mathrm{m}^{2} /\right.$ hari)

$\mathrm{C}_{\mathrm{o}}=$ Kandungan $\mathrm{N}$ dan $\mathrm{P}$ rumput laut di awal pemeliharaan (mg DW/g)
$C_{t}=$ Kandungan $\mathrm{N}$ dan $\mathrm{P}$ rumput laut di akhir pemeliharaan ( $\mathrm{mg} \mathrm{DW} / \mathrm{g}$ )

$\alpha=$ Biomassa kering rumput laut per area budidaya $\left(\mathrm{g} / \mathrm{m}^{2}\right)$

$\mathrm{t}=$ Lama pemeliharaan (hari)

Data pertumbuhan dan penyerapan $\mathrm{N}$ dan $P$ rumput laut selanjutnya diuji secara statistik menggunakan analisis ragam (ANOVA) pada selang kepercayaan 95\% dengan software Minitab 16. Jika respons yang dihasilkan berbeda nyata maka dilakukan uji lanjut menggunakan Tukey tes.

\section{HASIL DAN BAHASAN}

\section{Kondisi Kualitas Perairan}

Kondisi kualitas air merupakan faktor penting yang harus diperhatikan dalam kegiatan budidaya rumput laut karena air merupakan media yang secara langsung memengaruhi aktivitas budidaya rumput laut. Parameter kualitas air yang memengaruhi pertumbuhan rumput laut antara lain: suhu, salinitas, intensitas cahaya, nutrien, dan kecepatan arus (Parenrengi et al., 2011). Berdasarkan hasil pengukuran parameter kualitas air (parame- 
ter fisik dan kimia perairan) selama pemeliharaan rumput laut $K$. alvarezii dan E. spinosum, menunjukkan bahwa kondisi kualitas air di Teluk Gerupuk masih mendukung kegiatan budidaya rumput laut (Tabel 2).

Menurut Tiongsungrusmee (1990), suhu perairan yang ideal untuk budidaya rumput laut Eucheuma adalah berkisar antara $25^{\circ} \mathrm{C}$ $30^{\circ} \mathrm{C}$, sedangkan salinitas berkisar $28-34 \mathrm{~g} / \mathrm{L}$. Dari hasil pengujian kualitas air di lokasi penelitian, termasuk pada kisaran optimal untuk budidaya rumput laut yaitu berkisar antara $26,8^{\circ} \mathrm{C}-28^{\circ} \mathrm{C}$ dan $31-35 \mathrm{~g} / \mathrm{L}$ (Parenrengi et al., 2011 ). Kecerahan juga menjadi faktor yang penting yang berhubungan dengan ketersediaan sinar matahari untuk proses fotosintesis rumput laut untuk mendukung pertumbuhannya. Menurut Mubarak et al. (1990), kecerahan yang baik untuk pertumbuhan rumput laut berkisar 3-5 m. Hasil pemantauan di lokasi penelitian, menunjukkan bahwa tingkat kecerahan pada lokasi budidaya rumput laut berkisar 2,5-3 m (Tabel 2).

Secara umum telah diketahui rumput laut mendapatkan pertumbuhan yang lebih baik pada air yang bergerak (arus). Pergerakan air berfungsi untuk membersihkan tanaman, menghadirkan nutrisi baru, merangsang pertumbuhan tanaman melalui gaya/kekuatan hidrolik gerakan air, dan mencegah adanya fluktuasi suhu air yang besar. Kecepatan arus yang ideal untuk budidaya rumput laut berkisar 20-40 cm/detik (Parenrengi et al., 2011).

Dampak utama dari keberadaan aktivitas budidaya ikan yang menggunakan pakan buatan terhadap kualitas perairan di sekitarnya yaitu terjadinya peningkatan akumulasi partikel dan nutrien terlarut di kolom air (Nordvarg \& Johansson, 2002). Nutrien sangat berperan dalam pertumbuhan rumput laut khususnya kandungan nitrogen dan fosfat (Parenrengi et al., 2011).

Analisis vertikal parameter $\mathrm{NO}_{3}-\mathrm{N}$ dan $\mathrm{PO}_{4}-$ P ditampilkan pada Gambar 2. Dari hasil analisis tersebut, terlihat secara jelas bahwa pada hari ke-30 sebaran konsentrasi $\mathrm{NO}_{3}-\mathrm{N}$ perairan terakumulasi paling banyak pada sisi barat dari KJA IMTA dengan kisaran antara 0,5$1,1 \mathrm{mg} / \mathrm{L}$. Sedangkan untuk sebaran konsentrasi $\mathrm{PO}_{4}-\mathrm{P}$ tertinggi terdapat pada sisi timur KJA IMTA dengan kisaran nilai 0,05-0,39 mg/L (Gambar 2A). Di akhir masa penelitian rumput laut (hari ke-45) penyebaran nutrien terlarut baik $\mathrm{NO}_{3}-\mathrm{N}$ maupun $\mathrm{PO}_{4}-\mathrm{P}$ terakumulasi paling

Tabel 2. Statistik deskriptif kualitas perairan di Teluk Gerupuk, Lombok Tengah Table 2. Descriptive statistic of water quality in Gerupuk Bay, Central Lombok

\begin{tabular}{|c|c|c|c|c|c|c|}
\hline $\begin{array}{l}\text { Parameter } \\
\text { Parameters }\end{array}$ & $\begin{array}{l}\text { Unit } \\
\text { Unit }\end{array}$ & $\begin{array}{l}\text { Minimum } \\
\text { Minimum }\end{array}$ & $\begin{array}{l}\text { Maksimum } \\
\text { Maximum }\end{array}$ & $\begin{array}{c}\text { Rataan } \\
\text { Mean }\end{array}$ & $\begin{array}{c}\text { Standar } \\
\text { deviasi } \\
\text { Standard } \\
\text { deviation }\end{array}$ & $\begin{array}{l}\text { Baku mut u } \\
\text { Standard } \\
\text { value }\end{array}$ \\
\hline Kecerahan (Transparency) & M & 2.5 & 3 & 2.67 & 0.24 & $>5^{*}$ \\
\hline Suhu (Temperature) & ${ }^{\circ} \mathrm{C}$ & 26.86 & 28.05 & 27.31 & 0.49 & $25-30$ \#) \\
\hline $\mathrm{pH}$ & & 8.18 & 8.92 & 8.58 & 0.28 & \\
\hline DO (Dissolved oxygen) & $\mathrm{mg} / \mathrm{L}$ & 4.1 & 6.89 & 5.99 & 0.76 & $>5^{* * *}$ \\
\hline TDS (Total dissolved solid) & $\mathrm{mg} / \mathrm{L}$ & 31.02 & 34.58 & 33.16 & 1.14 & \\
\hline Konduktivitas (Conductivity) & $\mu S / \mathrm{cm}$ & 51.51 & 53 & 53.59 & 1.47 & \\
\hline Salinitas (Salinity) & $g / L$ & 31 & 35.64 & 33.46 & 1.35 & $28-34^{\star *}$ \\
\hline $\begin{array}{l}\text { Kecepatan arus } \\
\text { Water current }\end{array}$ & $\mathrm{m} / \mathrm{s}$ & 0.40 & 0.6 & 0.50 & 0.14 & $\left.0.20-0.40^{*}\right)$ \\
\hline $\mathrm{NO}_{3}-\mathrm{N}$ & $\mathrm{mg} / \mathrm{L}$ & 0.001 & 1.1 & 0.62 & 0.28 & \\
\hline $\mathrm{NO}_{2}-\mathrm{N}$ & $\mathrm{mg} / \mathrm{L}$ & 0.01 & 0.5 & 0.06 & 0.13 & \\
\hline $\mathrm{PO}_{4}-\mathrm{P}$ & $\mathrm{mg} / \mathrm{L}$ & 0.04 & 0.4 & 0.16 & 0.12 & \\
\hline
\end{tabular}

Baku mutu berdasarkan (Standard value according to): ") Parenrengi et al. (2011); **) Tiongsungrusmee (1990); $\left.{ }^{* * *}\right)$ Kementerian Kependudukan dan Lingkungan Hidup No. 51 tahun 2004 (Ministry of Demography and Live Environment acreement number 51, 2014) 

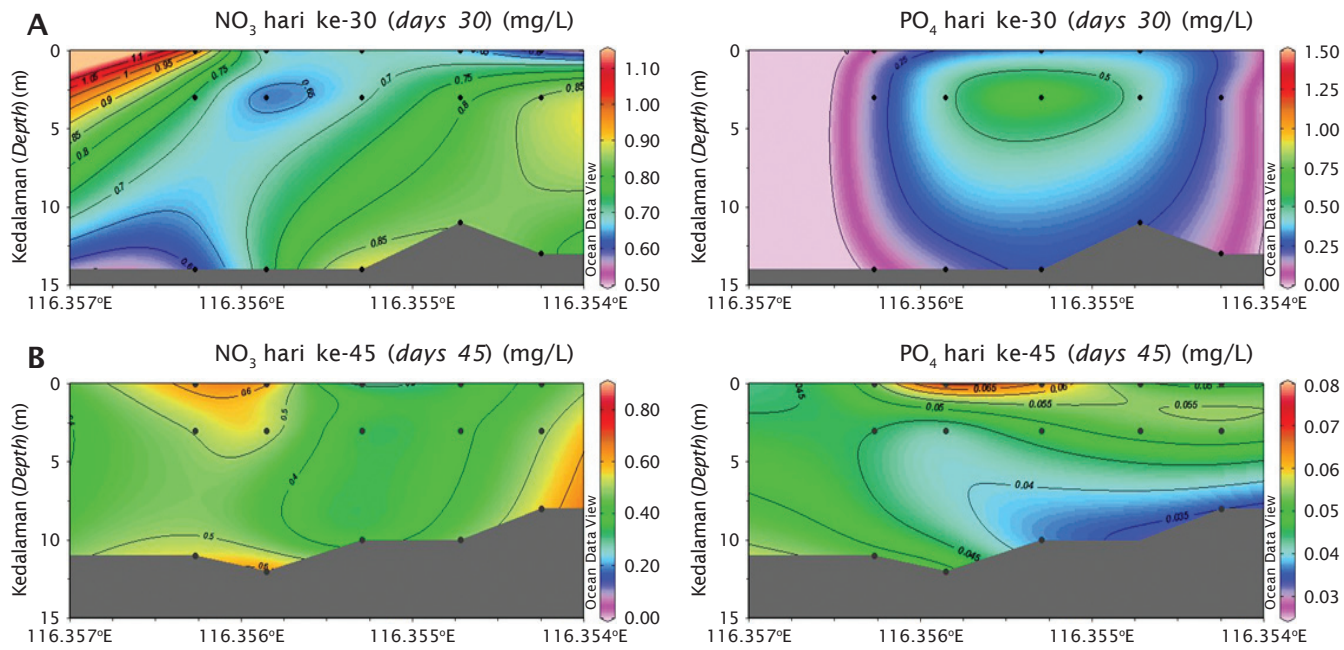

Gambar 2. Analisis vertikal kualitas perairan di lokasi IMTA Teluk Gerupuk: hari ke-30 (A) dan hari ke-45 (B)

Figure 2. Vertical overview of water quality in IMTA area of Gerupuk Bay: days 30 (A) and days $45(B)$

banyak pada sisi barat KJA IMTA (Gambar 2B). Perbedaan distribusi nutrien yang teramati selama penelitian dapat disebabkan oleh pola arus yang terjadi di Teluk Gerupuk. Arus di Teluk Gerupuk umumnya didominasi oleh arus pasang surut. Pola penyebaran nutrien ini secara langsung akan memengaruhi pertumbuhan rumput laut yang dibudidayakan di sisi barat dan sisi timur KJA IMTA.

\section{Perfomansi Pertumbuhan dan Produk- tivitas Rumput Laut}

Peningkatan bobot rata-rata $K$. alvarezii yang dibudidayakan di lokasi IMTA mencapai $4.114,36 \mathrm{~g} / \mathrm{m}^{2}$ atau $89,87 \%$ lebih tinggi dibandingkan $K$. alvarezii di lokasi kontrol (Gambar 3A). Hal ini berkorelasi positif dengan peningkatan kandungan nitrogen pada jaringan rumput laut tersebut di lokasi IMTA (Gambar 2). Rumput laut sangat membutuhkan nitrogen karena fungsinya sebagai pemacu pertumbuhan (Anonim, 2002; Parenrengi et al., 2011). Hasil analisis ragam (ANOVA) untuk biomassa rumput laut juga menunjukkan bahwa $\mathrm{K}_{\mathrm{a}} \mathrm{B}$ dan $\mathrm{K}_{\mathrm{a}} \mathrm{T}$ memiliki biomassa akhir yang secara signifikan berbeda dengan $\mathrm{K}_{\mathrm{a}} \mathrm{K}(\mathrm{P}<0,05)$; sedangkan untuk antara $\mathrm{K}_{\mathrm{a}} \mathrm{B}$ dan $\mathrm{K}_{\mathrm{a}}^{\mathrm{T}}$ biomassa akhir tidak berbeda nyata $(P>0,05)$.

Parenrengi et al. (2011) mengungkapkan bahwa penggunaan nutrien $\mathrm{NH}_{4}$ pada konsentrasi $10 \mathrm{mM}$ selama satu jam setiap tiga ha- ri pada budidaya rumput laut $K$. alvarezii di tanki dan di laut memperlihatkan pertumbuhan dua kali lipat dibandingkan dengan kontrol. Glenn \& Doty (1981) menunjukkan bahwa Eucheuma memanfaatkan 24\% nitrat/nitrit ion dan $6 \%$ fosfat dari air yang melewati rumpun rumput laut tersebut dan rata-rata perbandingan N/P di air adalah 8,5 pada air laut tempat budidaya Eucheuma. Rumput laut biasanya memiliki laju pertumbuhan yang tinggi ketika berada di lingkungan yang kaya nitrogen dan fosfor (Oliveira et al., 2012).

Pada rumput laut jenis E. spinosum, dengan bobot awal yang sama, rata-rata pertambahan bobot pada long line barat $\left(\mathrm{E}_{\mathrm{s}} \mathrm{B}\right)$ di hari ke45 mencapai $3.698,2 \mathrm{~g} / \mathrm{m}^{2}$ atau lebih tinggi $57,55 \%$ daripada long line kontrol $\left(\mathrm{E}_{\mathrm{s}} \mathrm{K}\right)$ yaitu $2.347,3 \mathrm{~g} / \mathrm{m}^{2}$. E. spinosum yang ditanam pada long line timur $\left(\mathrm{E}_{\mathrm{s}} \mathrm{T}\right)$ mencapai bobot rata-rata pada akhir masa pemeliharaan yaitu $2.488,62$ $\mathrm{g} / \mathrm{m}^{2}$, lebih tinggi $6,02 \%$ daripada long line kontrol $\left(E_{s} K\right)$ yang mencapai bobot rata-rata akhir $2.347,3 \mathrm{~g} / \mathrm{m}^{2}$ (Gambar 3B). Hal ini diperkuat dengan hasil analisis ragam, di mana $E_{s} B$ saja memiliki biomassa akhir yang berbeda signifikan dengan biomassa akhir $\mathrm{E}_{\mathrm{s}} \mathrm{K}(\mathrm{P}<0,05)$.

Pada akhir masa pemeliharaan, nilai biomassa rumput laut $K$. alvarezii dan E. spinosum di lokasi IMTA mengalami peningkatan antara $211,07 \%-414,29 \%$; peningkatan ini lebih tinggi dibandingkan dengan lokasi kon- 

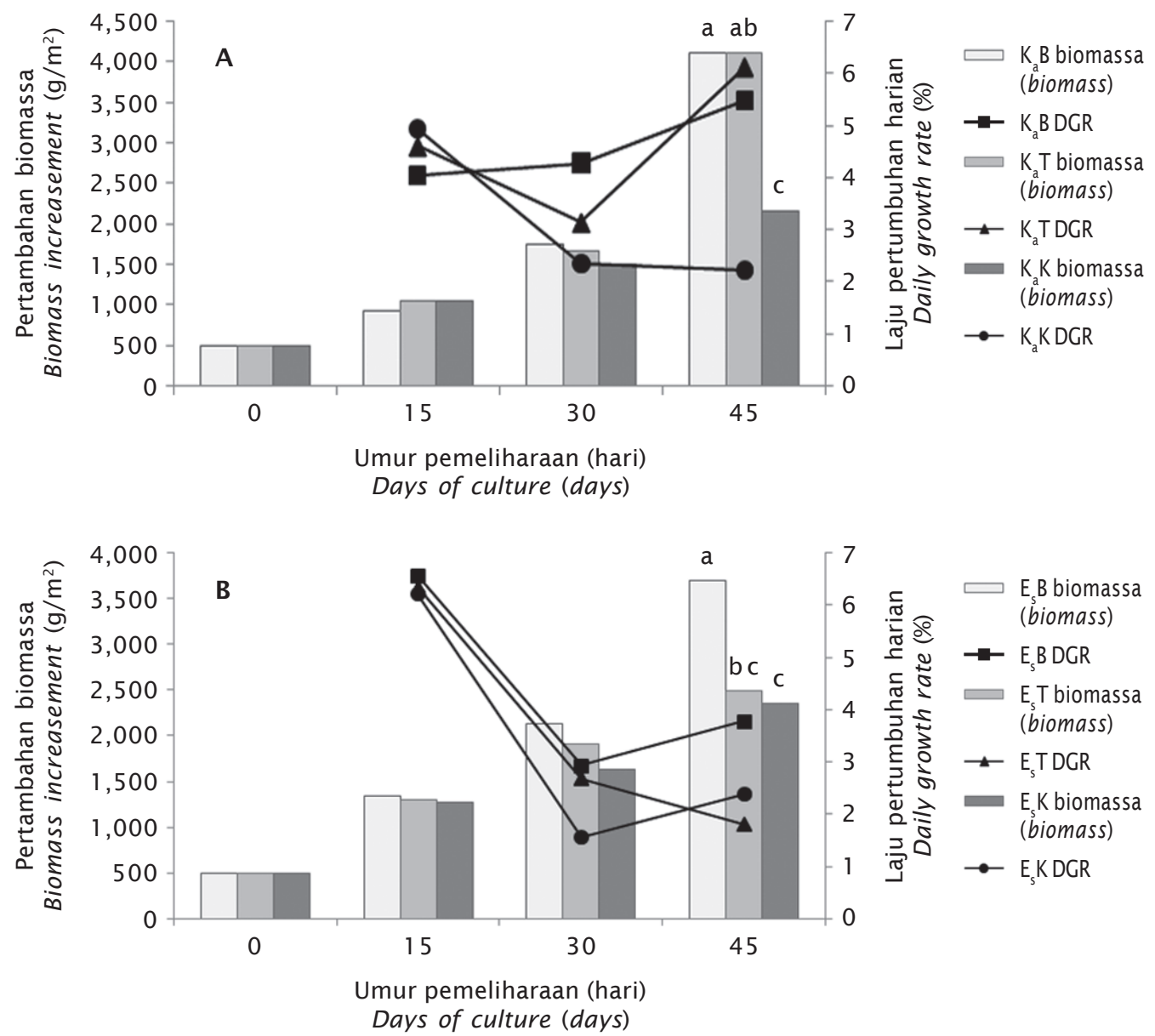

Gambar 3. Pertambahan bobot dan laju pertumbuhan harian (DGR) rumput laut: $K$. alvarezii (A) dan E. spinosum (B). Huruf superscript yang berbeda menunjukkan perbedaan nyata pada taraf uji 5\% (uji Tukey)

Figure 3. Biomass increasement and daily growth rate (DGR) of seaweeds: $K$. alvarezii $(A)$ and E. spinosum (B). Different superscript letters indicate significant differences at level test $5 \%$ (Tukey test)

trol. Kondisi ini dapat disebabkan karena adanya pelepasan bahan nutrien terlarut yang dihasilkan oleh KJA ikan, terutama berasal dari limbah metabolik ikan. Wang et al. (2012) mengemukakan bahwa kegiatan budidaya ikan dapat menghasilkan limbah karbon (C), nitrogen $(\mathrm{N})$, dan fosfor $(\mathrm{P})$. Di mana $\mathrm{N}$ inorganik terlarut $\left(\mathrm{NH}_{3}\right)$ dilepaskan melalui proses eksresi dan $\mathrm{C}$ inorganik seperti $\mathrm{CO}_{2}$ dilepaskan melalui proses respirasi. Hal tersebut juga mengindikasikan bahwa baik K. alvarezii maupun E. spinosum dapat mengasimilasi nitrogen inorganik terlarut yang banyak terdapat di lokasi IMTA menjadi bahan organik yang berperan penting bagi pertumbuhan melalui proses fotosintesis. Kemampuan kedua jenis rumput laut dalam mengasimilasi dan menyimpan nitrogen secara cepat untuk pertumbuhan membuat alga tersebut dapat memperoleh keuntungan dari melimpahnya konsentrasi nutrien terlarut yang dihasilkan KJA (Troell et al., 1997).

Produktivitas budidaya rumput laut $K$. alvarezii pada unit long line di lokasi IMTA ( $\mathrm{K}_{\mathrm{a}} \mathrm{B}$ dan $\mathrm{K}_{\mathrm{a}} \mathrm{T}$ ) yaitu 20,56-20,57 ton/ha/tahun, dua kali lebih tinggi dari $K$. alvarezii yang dibudidayakan pada long line kontrol $\left(\mathrm{K}_{\mathrm{a}} \mathrm{K}\right)$ yaitu 
10,83 ton/ha/tahun. Sedangkan total biomassa panen $E$. spinosum pada lokasi IMTA lebih tinggi satu setengah kali $(12,44-18,49$ ton/ha/tahun) dibandingkan dengan kontrol yaitu 11,73 ton/ha/tahun (Tabel 3).

\section{Laju Penyerapan Nitrogen dan Fosfor Rumput Laut}

Nitrogen merupakan satu unsur utama penyusun sel organisme dalam pembentukan protoplasma. Dalam perairan, nitrogen hadir dalam bentuk nitrat, nitrit, amonium, dan amonia, serta senyawa-senyawa $\mathrm{N}$-organik seperti urea dan asam amino (Effendi, 2003). Dissolved Inorganic Nutrient/DIN (meliputi $\mathrm{NH}_{4}$, $\mathrm{NO}_{3}$, dan $\mathrm{NO}_{2}$ ) merupakan faktor pembatas yang menentukan produktivitas rumput laut di berbagai lingkungan laut (Troell et al., 2009).

Hasil pengujian kandungan nitrogen pada jaringan rumput laut $K$. alvarezii di akhir masa pemeliharaan diperoleh bahwa kandungan nitrogen $\mathrm{K}_{\mathrm{a}} \mathrm{B}$ pada hari ke-45 mencapai $4,73 \mathrm{~g} \mathrm{~N} / \mathrm{m}^{2}$ atau lebih tinggi $148,1 \% \mathrm{di}$ bandingkan dengan $\mathrm{K}_{\mathrm{a}} \mathrm{K}$ yaitu hanya mencapai $1,91 \mathrm{~g} \mathrm{~N} / \mathrm{m}^{2}$. Sedangkan untuk $\mathrm{K}_{\mathrm{a}} \mathrm{T}$ kandungan nitrogennya mencapai $4,40 \mathrm{~g} \mathrm{~N} / \mathrm{m}^{2}$ atau $130,8 \%$ lebih tinggi dibandingkan dengan $\mathrm{K}_{\mathrm{a}} \mathrm{K}$ (Gambar 4A). Kemampuan penyerapan nitrogen oleh rumput laut E. spinosum, hampir serupa dengan $K$. alvarezii, di mana kandung- an nitrogen pada jaringan rumput laut $\mathrm{E}_{\mathrm{s}} \mathrm{B}$ pada hari ke-45 mencapai 4,36 g N/m²; lebih tinggi $32,79 \%$ dibandingkan dengan $\mathrm{E}_{\mathrm{s}} \mathrm{K}$ yaitu $3,29 \mathrm{~g} \mathrm{~N} / \mathrm{m}^{2}$. Sedangkan untuk $\mathrm{E}_{\mathrm{s}} T$ kandungan nitrogennya mencapai nilai $3,53 \mathrm{~g} \mathrm{~N} / \mathrm{m}^{2}$; atau lebih tinggi 7,54\% dibandingkan dengan $\mathrm{E}_{\mathrm{s}} \mathrm{K}$ (Gambar 4B).

Berdasarkan analisis kandungan nitrogen pada jaringan rumput laut, biomassa rumput laut dan luasan areal budidaya dari dua spesies rumput laut yaitu K. alvarezii dan E. spinosum yang dibudidayakan pada long line IMTA dan kontrol, menunjukkan laju penyerapan nitrogen $K$. alvarezii pada lokasi IMTA memiliki nilai lebih tinggi dengan kisaran 80,03-86,95 ton/ha/tahun; dibandingkan dengan kontrol yaitu 15,61 ton/ha/tahun (Gambar 5). Untuk jenis $E$. spinosum laju penyerapan nitrogen di lokasi IMTA berkisar antara 35, 14-69,78 ton/ ha/tahun, lebih tinggi dibandingkan dengan long line kontrol yaitu sejumlah 30,53 ton/ha/ tahun (Gambar 5). Hal tersebut terjadi akibat akumulasi nutrien terlarut di unit IMTA, khususnya di long line barat dengan konsentrasinya cukup tinggi dibandingkan lokasi lainnya (long line timur dan kontrol) (Gambar 2). Penelitian Nishihara et al. (2010) menemukan bahwa kandungan nutrien pada area rumpun E. serra $56 \%$ lebih sedikit dibandingkan di luar area rumpun rumput laut tersebut.

Tabel 3. Parameter budidaya rumput laut $K$. alvarezii dan E. spinosum pada sistem IMTA dan kontrol

Table 3. Parameters seaweed culture of $K$. alvarezii and E. spinosum at IMTA system and control

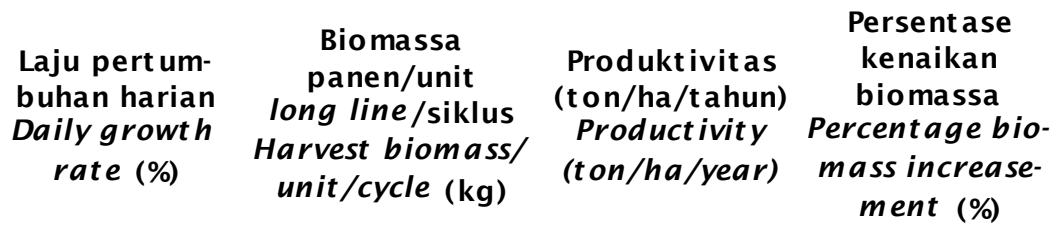

\section{K. alvarezii}

Barat (West)

4.68

$2,571.48$

20.57

414.29

Timur (East)

4.68

$2,570.88$

20.56

414.17

Kontrol (Control)

3.26

$1,354.56$

10.83

170.9

\section{E. spinosum}

Barat (West)

4.45

$2,311.38$

18.49

362.27

Timur (East)

3.57

$1,555.39$

12.44

211.07

Kontrol (Control)

3.44

$1,467.06$

11.73

193.41 


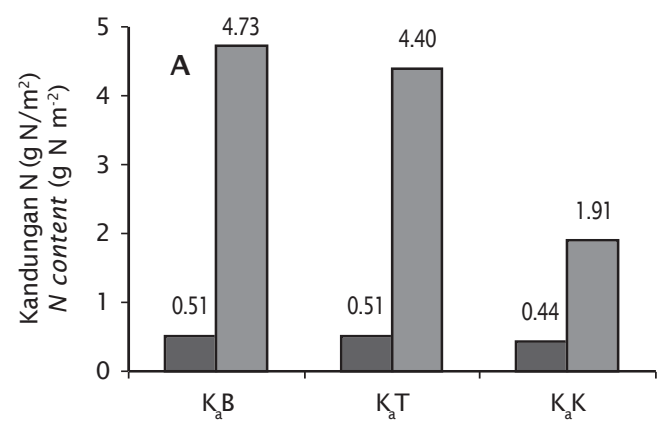

$\square \mathrm{N}$ awal ( $N$ initial) $\square \mathrm{N}$ akhir ( $N$ final)

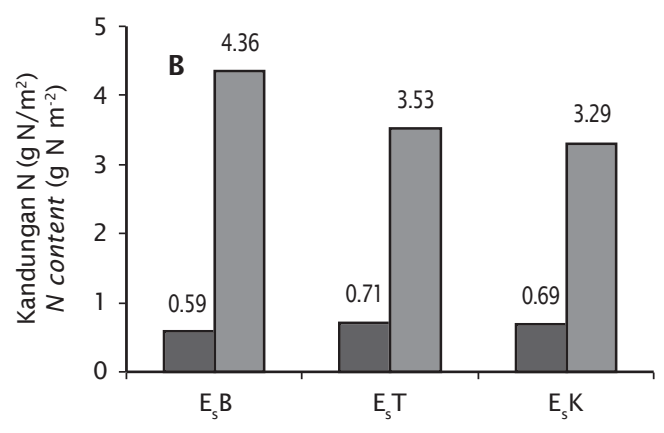

$\mathrm{N}$ awal ( $N$ initial) $\square \mathrm{N}$ akhir ( $N$ final) Rumput laut (Seaweed)

Gambar 4. Kandungan nitrogen pada rumput laut K. alvarezii (A) dan E. Spinosum (B)

Figure 4. Nitrogen content of seaweed K. alvarezii (A) and E. spinosum (B)

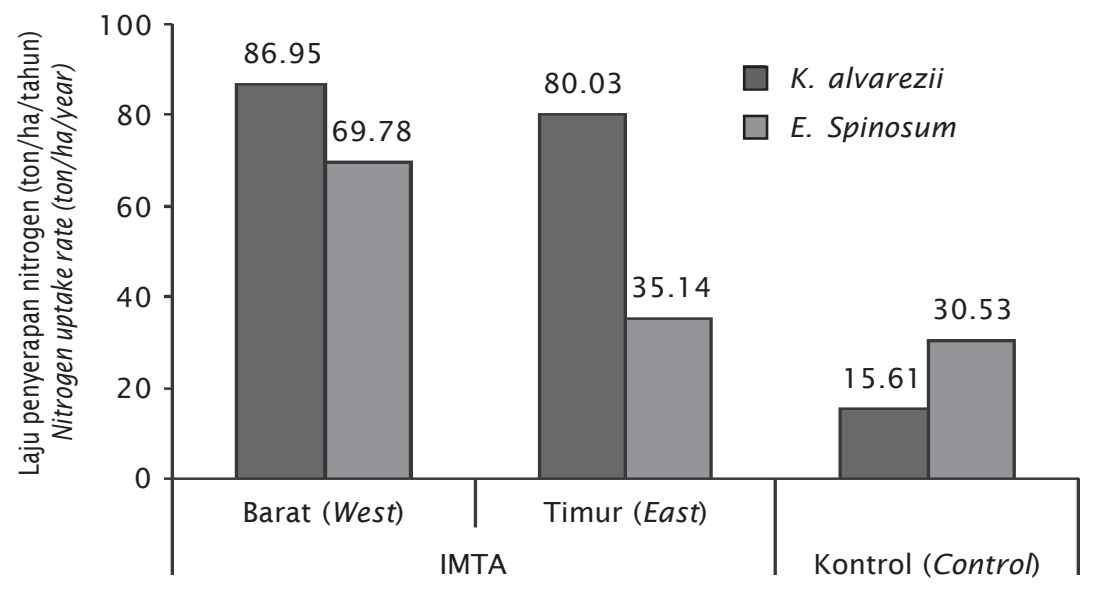

Gambar 5. Laju penyerapan nitrogen K. alvarezii dan E. Spinosum

Figure 5. The nitrogen absorption rate of $K$. alvarezii and $E$. spinosum

Fosfor juga merupakan unsur yang esensial bagi tumbuhan tingkat tinggi dan alga, sehingga unsur ini menjadi faktor pembatas bagi tumbuhan dan alga akuatik, serta sangat memengaruhi tingkat produktivitas perairan (Effendi, 2003). Kandungan fosfor pada rumput laut $K$. alvareziii dan E. spinosum yang dibudidayakan dengan sistem IMTA relatif lebih tinggi dengan kisaran 0,55-1,07 g P/m² dibandingkan dengan rumput laut yang dibudidayakan di lokasi kontrol (Gambar 6).

Pada rumput laut jenis $K$. alvarezii, kandungan fosfor terbaik terdapat pada $\mathrm{K}_{\mathrm{a}} \mathrm{T}$ dengan kandungan total P sejumlah $1,07 \mathrm{~g} P$ $\mathrm{DW} / \mathrm{m}^{2}$; sedangkan untuk jenis $E$. spinosum kandungan total $\mathrm{P}$ pada jaringan rumput laut tertinggi terdapat pada $E_{s} B$ dengan nilai 0,55 $\mathrm{g} \mathrm{P} / \mathrm{m}^{2}$; lebih tinggi 39\% dibandingkan dengan kontrol ( $\left.\mathrm{E}_{\mathrm{s}} \mathrm{K}\right)$. (Gambar 6).

Rumput laut $K$. alvarezii memiliki nilai laju penyerapan fosfor yang lebih tinggi dibandingkan dengan E. spinosum di semua lokasi budidaya. Laju penyerapan fosfor K. alvarezii tertinggi terdapat pada sisi timur KJA IMTA $\left(\mathrm{K}_{\mathrm{a}} \mathrm{T}\right)$ dengan nilai mencapai lima kali lipat yaitu 20,56 ton $\mathrm{P} / \mathrm{ha}$ /tahun dibandingkan dengan laju penyerapan fosfor $E$. spinosum yaitu 4,39 ton P/ha/tahun. Sedangkan untuk E. spinosum laju penyerapan fosfor tertinggi terdapat pada sisi sebelah barat KJA IMTA $\left(\mathrm{E}_{\mathrm{s}} \mathrm{B}\right)$ dengan nilai mencapai 8,69 ton $\mathrm{P} / \mathrm{ha} /$ tahun (Gambar 7). 


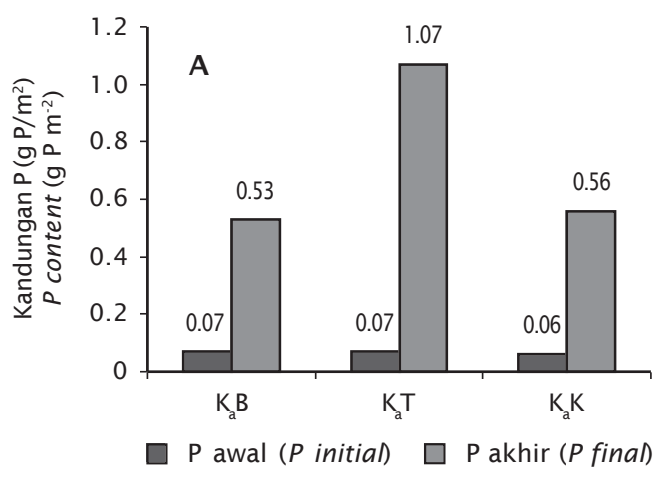

Rumput laut (Seaweed)

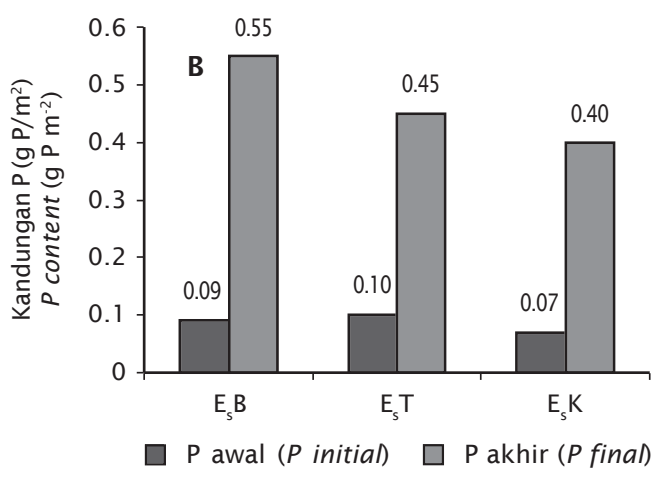

Rumput laut (Seaweed)

Gambar 6. Kandungan fosfor pada rumput laut K. alvarezii (A) dan E. spinosum (B)

Figure 6. Phosphorus content in seaweed $K$. alvarezii $(A)$ and $E$. spinosum (B)

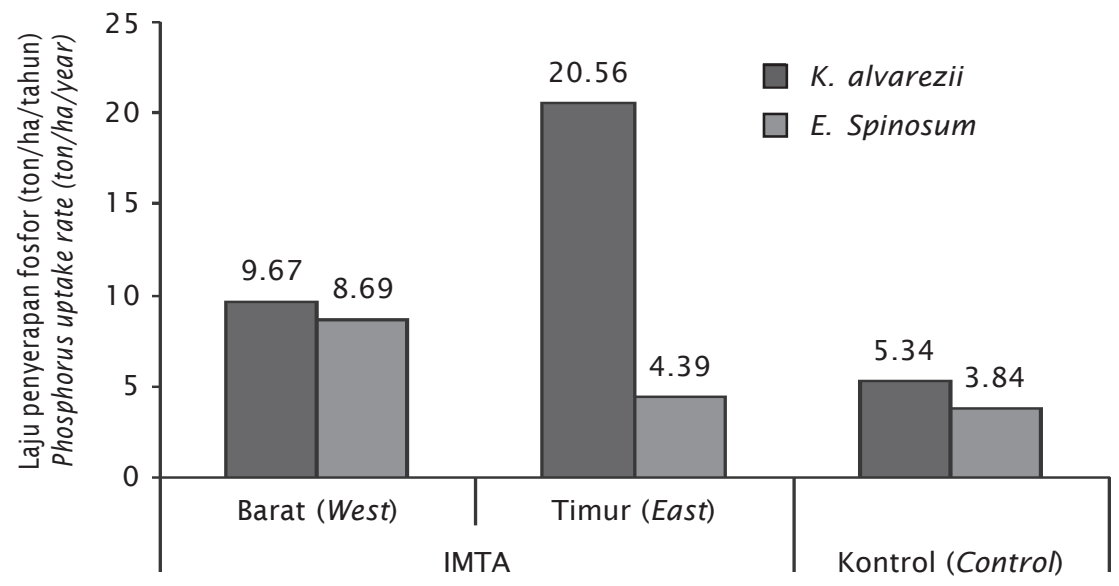

Gambar 7. Laju penyerapan fosfor K. alvarezii dan E. spinosum

Figure 7. The phosphorus absorption rate of $K$. alvarezii and $E$. spinosum

Laju penyerapan fosfor yang tinggi mengindikasikan $K$. alvarezii pada long-line timur $\left(\mathrm{K}_{\mathrm{a}} \mathrm{T}\right)$ dapat mengasimilasi $\mathrm{PO}_{4}-\mathrm{P}$ terlarut di air dengan baik. Hasil penelitian Neori et al. (2004) menunjukkan bahwa spesies alga yang berbeda memiliki kemampuan dalam menyerap nutrien ( $\mathrm{N}$ dan $\mathrm{P}$ ) yang berbeda pula. Selain pengaruh dari arus, konsentrasi nutrien, intensitas cahaya, dan bobot, keberadaan dari biofouling juga dapat membatasi kemampuan rumput laut dalam menyerap nutrien (Troell et al., 2003). Menurut Rees (2003), laju penyerapan nitrat, amonium, dan fosfat oleh rumput laut menunjukkan pola yang hampir sama, namun nilai pengambilannya lebih rendah untuk fosfat dan lebih tinggi untuk amonium.

\section{Penyerapan Nitrogen dan Fosfor Rumput Laut di Teluk Gerupuk}

Berdasarkan laju penyerapan nutrien ( $N$ dan $\mathrm{P}$ ), biomassa panen, dan luasan area budidaya, maka dapat dilakukan estimasi potensi penyerapan nitrogen dan fosfor oleh aktivitas budidaya rumput laut sebagai dampak positif dari penerapan IMTA pada kegiatan budidaya laut yang dilakukan di Teluk Gerupuk, Lombok Tengah. Dengan asumsi luas area potensial budidaya rumput laut mencapai 322 ha (Radiarta \& Rasidi, 2012), maka potensi perairan teluk ini dalam menyerap nitrogen dan fosfat melalui kegiatan budidaya rumput laut berbasis IMTA masing-masing adalah 22.470,04-27.996,93 ton dan 2.796,82- 
Tabel 4. Potensi penyerapan nitrogen dan fosfor oleh rumput laut di kawasan Teluk Gerupuk Table 4. Potency of nitrogen and phosphorus absorption by seaweed in Gerupuk Bay area

\begin{tabular}{clcccc}
\hline $\begin{array}{c}\text { Spesies } \\
\text { Species }\end{array}$ & \multicolumn{1}{c}{$\begin{array}{c}\text { Metode } \\
\text { Methode }\end{array}$} & LPN & PPN & LPP & PPP \\
\hline \multirow{2}{*}{ K alvarezii } & IMTA & 86.95 & $27,996.93$ & 20.56 & $6,619.16$ \\
& Kontrol (Control) & 15.61 & $5,025.43$ & 5.34 & $1,718.69$ \\
\hline \multirow{2}{*}{ E spinosum } & IMTA & 69.78 & $22,470.04$ & 8.69 & $2,796.82$ \\
& Kontrol (Control) & 30.53 & $9,830.41$ & 3.84 & $1,234.95$ \\
\hline
\end{tabular}

Keterangan (Note):

LPN = Laju penyerapan $\mathrm{N}$ (ton/ha/tahun) (N uptake rate (ton/ha/year)), PPN = Potensi penyerapan $\mathrm{N}(\mathrm{N}$ uptake potency) (ton N), LPP = Laju penyerapan $\mathrm{P}$ (ton/ha/tahun) $(P$ uptake rate $($ ton $/$ ha/year $))$, PPP = Potensi penyerapan $\mathrm{P}$ ( $P$ uptake potency) (ton $\mathrm{P}$ )

6.619,16 ton (Tabel 4). Hasil penelitian Chopin et al. (2010) tentang penerapan IMTA dalam skala kecil di pantai Timur Kanada menunjukkan bahwa pemanenan alga dari suatu lokasi budidaya sama dengan menghilangkan nitrogen dari ekosistem tersebut sejumlah 35,75 $\mathrm{mt}$ dan fosfor sejumlah 4,09 mt.

\section{Perspektif Penyerapan N dan P Rumput Laut Terhadap Pengembangan Budi- daya Laut Terintegrasi}

Dalam rangka mendukung upaya peningkatan produktivitas perikanan budidaya, KKP telah mencanangkan kebijakan minapolitan yang merupakan suatu konsep pembangunan berbasis kawasan, industrialisasi, dan ekonomi biru (blue economy). Budidaya rumput laut berbasis IMTA dapat dijadikan salah satu aktivitas dalam penerapan prinsip-prinsip kebijakan ekonomi biru KKP yang meliputi: (1) efisiensi sumber daya alam melalui peningkatan nilai tambah komoditas dan diversifikasi produk untuk dapat menghasilkan manfaat ekonomi yang lebih besar dengan memanfaatkan sumber daya alam lebih hemat, dan (2) tanpa limbah dan emisi, di mana prinsip ini sangat berkaitan erat dengan upaya efisiensi sumber daya alam dengan cara pemanfaatan seluruh unsur yang terkandung dalam sistem IMTA menjadi komoditas lain yang bernilai ekonomis tinggi sehingga tidak menyisakan limbah (zero waste). Selain itu, penerapan budidaya rumput laut berbasis IMTA yang dilaksanakan di Teluk Gerupuk sesuai dengan pola pendekatan implementasi dari kebijakan ekonomi biru KKP yaitu pengembangan kawasan blue economy yang dilakukan dengan pola pembangunan berbasis: (1) gugusan pulau-pulau, (2) kawasan teluk dan pesisir, serta (3) kawasan konservasi (KKP, 2013). Identifikasi potensial jenis rumput laut lainnya perlu dilakukan guna meningkatkan diversifikasi jenis yang dibudidayakan.

\section{KESIMPULAN}

Hasil dari penelitian mengindikasikan bahwa rumput laut memiliki kemampuan dalam menyerap $\mathrm{N}$ dan $\mathrm{P}$ dari perairan. Rumput laut jenis Kappaphycus alvarezii memiliki kemampuan dalam menyerap nitrogen dan fosfor lebih baik dibandingkan dengan jenis Eucheuma spinosum. Kemampuan kedua jenis rumput laut tersebut dalam menyerap $\mathrm{N}$ dan $\mathrm{P}$ dari kawasan Teluk Gerupuk dapat dijadikan salah satu indikator bahwa pengembangan budidaya rumput laut berbasis IMTA mendukung pengembangan budidaya laut yang berorientasi pada peningkatan produksi (biomass) dan penurunan dampak lingkungan (aktivitas tanpa limbah/zero waste).

\section{UCAPAN TERIMA KASIH}

Penulis mengucapkan terima kasih kepada Pusat Penelitian dan Pengembangan Perikanan Budidaya, Kementerian Kelautan dan Perikanan yang telah memberikan dukungan finansial dalam pelaksanaan penelitian ini. Kami juga mengucapkan terima kasih kepada Balai Budidaya Laut Lombok yang telah memberikan bantuan teknis selama penelitian berlangsung. Terima kasih juga diucapkan kepada Erlania, M.Si., Bapak Buntaran, M.Si., Bapak Rusman, M.Si., dan Bapak Seme yang telah membantu kelancaran penelitian di lapangan. 


\section{DAFTAR ACUAN}

Abreu, M.H., Varela, D.A., Henriquez, L., Villarroel, A., Yarish, C., Sousa-Pinto, L., \& Buschmann, A.H. (2009). Traditional vs integrated multi tropic aquaculture of Gracilaria chilensis. Bird, C.J., McLachlan, J., \& Oliviera, E.C.: productivity and physiological performance. Aquaculture, 293, 211220.

Anonim. (2002). Teknik budidaya rumput laut bahan pembuat agar-agar di dalam tambak. BPPT, 2 hlm.

American Public Health Association (APHA). (2005). Standard methods for the examination of water and wastewater. $21^{\text {st }}$ Edition. American Water Works Association (AWWA)/ American Public Works Association/Water Environment Federation. Washington. USA, $1,368 \mathrm{pp}$.

Atmadja, W.S., Susanto, A.B., \& Dhewani, N.M.S. (2012). Pengembangbiakan rumput laut (Makroalgae). Jakarta. Ikatan Fikologi Indonesia.

Chopin, T., Troell, M., Reid, G.K., Knowler, D., Robinson, S.M.C., Neori, A., Buschmann, A.H., \& Pang, S. (2010). Integrated multitrophic aquaculture. Part II: Increasing IMTA adoption Global Aquaculture Advocate November/December 2010, p. 17-20.

Effendi, H. (2003). Telaah kualitas air bagi pengelolaan sumber daya dan lingkungan perairan. Penerbit Kanisius. Yogyakarta.

Food Agricultural Organization [FAO]. (2012). The State of World Fisheries and Aquaculture 2012.Tersedia pada: www.fao.org

Glenn, E.P., \& Doty, M.S. (1981). Photosynthesis and respiration of the tropical red seaweeds. Eucheuma striatum (Tambalang and Elkhorn varieties) and E. denticulatum. Aquat. Bot., 10, 353-64.

Huo, Y., Wu, H., Chai, Z., Xu, S., Han, F., Dong, L., $\&$ He, P. (2012). Bioremediation efficiency of Gracilaria verrucosa for an integrated multi-trophic aquaculture system with Pseudosciaena crocea in Xiangshan harbor, China. Aquaculture, 326-329, 99-105.

Kitadai, Y., \& Kadowaki, S. (2007). The growth, $\mathrm{N}, \mathrm{P}$ uptake rates and photosyntetic rate of seaweeds cultured in coastal fish farm. Kagoshima University.

Kementerian Kelautan dan Perikanan [KKP]. (2013). Blue Economy, pembangunan Kelautan dan Perikanan berkelanjutan untuk kesejahteraan masyarakat. Kementerian
Kelautan dan Perikanan RI. Jakarta.

Luning, K. (1990). Seaweed: their environment, biogeography, and ecophysiology. John Wiley \& Sons, Inc. Canada, 527 pp.

Mubarak, H., Ilyas, S., Ismail, W., Wahyuni, I.S., Hartati, S.H., Pratiwi, E., Jangkaru, Z., \& Arifuddin, R. (1990). Petunjuk teknis budidaya rumput laut. Badan Litbang Pertanian, Puslitbang Perikanan. IDRC, Infish, $93 \mathrm{hlm}$.

Neori, A., Chopin, T., Troell, M., Buschmann, A.H., Kraemer, G.P., Halling, C., Shpigel, M., \& Yarish, C. (2004). Integrated aquaculture: rationale, evolution and state of the art emphasizing seaweed biofiltration in modern mariculture. Aquaculture, 231, 361-391.

Nishihara, Gregory, N., \& Terada, R. (2010). Spatial variations in nutrient supply to the red algae Eucheuma serra (J. Agardh). Phycological Res., 58(1), 29-34.

Nobre, A.M., Andersson, D.R., Neori, A., \& Sankar, K. (2010). Ecological-economic assesment of aquaculture options: Comparison between abalone monoculture and integrated multi-trophic aquaculture of abalone and seaweed. Aquaculture, 306, 116 126.

Nordvarg, L., \& Johansson, T. (2002). The effect of fish farm effluents on the water quality in the Aland archipelago, Baltic sea. Aquaculture Engineering, 25, 253-279.

Oliveira, V.P., Freire, F.A.M., \& Soriano, E.M. (2012). Influence of depth on the growth of the seaweed Gracilaria birdiae (Rhodophyta) in a shrimp pond. Braz. J. Aquat. Sci. Technol., 16(1), 33-39.

Parenrengi, A., Rachmansyah, \& Suryati, E. (2011). Budidaya rumput laut penghasil karaginan (karaginofit). Edisi Revisi. Balai Riset Perikanan Budidaya Air Payau, Badan Penelitian dan Pengembangan Kelautan dan Perikanan, Kementerian Kelautan dan Perikanan. Jakarta, $54 \mathrm{hlm}$.

Radiarta, I N., \& Rasidi. (2012). Analisa spasial kondisi kualitas perairan untuk mendukung budidaya rumput laut di Teluk Gerupuk Kabupaten Lombok Tengah Provinsi Nusa Tenggara Barat. Prosiding Seminar Nasional Perikanan Indonesia, $13-$ 14 November 2012. Sekolah Tinggi Perikanan. Jakarta.

Ren, J.S., Dozey, J.S., Plew, D.R., Fang, J., \& Gall, M. (2012). An ecosystem model for optimising production in integrated multitrophic aquaculture system. Journal Ecological Modelling, 246, 34-46. 
Rees, T.A.V. (2003). Safety factors and nutrient uptake by seaweeds. Mar. Eco. Prog. Ser., 263, 29-42.

Schlitzer, R. (2011). Ocean data view. WWW page. http://odv.awi.de.

Soto, D. (2009). Integrated mariculture: a global review (ed.). FAO Fisheries and Aquaculture Technical Paper. No. 529. FAO. Rome, 183 pp.

Tiensongrusmee, B. (1990). Site selection for Eucheuma spp. farming. UNDP/FAO Regional Seafarming Development and Demonstration Project (RAS/90/002). Kasetsart University Campus, Bangkok, Thailand. http://www.fao.org/docrep/field/003/ AB738E/AB738E00.htm\#TOC disadur tanggal 20 Mei 2014.

Troell, M., Halling, C., Nilsson, A., Buschmann, A.H., Kautsky, N., \& Kautsky, L. (1997). Integrated marine cultivation of Glacilarias chilensis (Gracilariales, Rhodophyta) and salmon cages for reduced environmental impact and increased economic output. Aquaculture, 156, 45-61.

Troell, M., Halling, C., Neori, A., Buschmann, A.H., Chopin, T., Yarish, C., \& Kautsky, N. (2003). Integrated Mariculture: asking the right question. Aquaculture, 226, 69-90.

Troell, M., Joyce, A., Chopin, T., Neori, A., Buschmann, A.H., \& Fang, J.G. (2009). Ecological engineering in aquaculture - potential for integrated multi-tophic aquaculture (IMTA) in marine offshore systems. Aquaculture, 297, 1-9.

Wang, X., Olsen, L.M., Reitan, K.I., \& Olsen, Y. (2012). Discharge of nutrient wastes from salmon farms: environmental effects, and potential for integrated multi-trophic aquaculture. Aquaculture environment interaction, 2, 267-283. 